\title{
Complementary Alternative Medicine Methods Preferred By Women Diagnosed With Urinary Tract Infections
}

\section{İdrar Yolu Enfeksiyonları Tanısı Alan Kadınların Tercih Ettikleri Tamamlayıcı Alternatif Tedavi Yöntemleri}

\author{
-Handan Ozcan', @irem Mut², @Ebru Karamanlı² \\ 'University of Health Sciences, Faculty of Health Sciences, Department of Midwifery, İstanbul, Turkey \\ ${ }^{2}$ Gumushane University, Faculty of Health Sciences, Department of Nurse, Gümüşhane, Turkey
}

\begin{abstract}
Introduction: The study was planned to determine the causes of infection in women diagnosed with urinary tract infections and the preferred complementary and alternative treatment methods of the women.

Material and Method: In the study, 180 women diagnosed with urinary tract infection (UTI) were interviewed. The required permissions were received. The data descriptive information form and Complementary and Alternative Medicine (CAM) Scale were used.

Results: The average age of women participating in the study is 40.21 $15.42 .73 .4 \%$ of the participants were diagnosed with more than one UTIs in one year. Almost all of the women who participated in the study stated that they used a complementary and alternative medicine method for UTIs (92.8\%) and $97.8 \%$ of them expressed that this method was effective.

The use of CAM methods was more common in those with higher education, housewifes or retired, women, those who performed vaginal douching had chronic diseases or incontinence. The use of CAM is less in those who are diagnosed with more than three UTIs in a year.

Conclusion: The most commonly used herbal methods are parsley, rosehip, green tea, nettle, linden, thyme and chamomile; dietary methods are yogurt, milk and dairy products, honey, pomegranate, garlic; religious methods are prayers; the psychological approach is exercise.
\end{abstract}

Keywords: Urinary tract infection, preference, women, complementary and alternative treatment methods
Öz

Amaç: Çalışma, idrar yolları enfeksiyon tanısı alan kadınlarda enfeksiyon sebepleri ve tercih ettikleri tamamlayıc ve alternatif tedavi yöntemlerini belirlemek için planlandı.

Gereç ve Yöntem: Çalışmada İdrar yolları enfeksiyonu (IYE) tanısı alan 180 kadınla görüşüldü. Gerekli izinler alındı. Veriler tanımlayıı bilgi formu ile Tamamlayıcı ve Alternatif Tıp Yaklaşımları Ölçeği kullanıldı.

Bulgular: Çalışmaya katılan kadınların yaş ortalaması 40.21 \pm 15.42 dir. Katılımcıların \%73.4'ü bir yılda birden fazla IYYE tanısı almış. Çalışmada kadınların hemen hemen hepsi IYE için (\%92.8) herhangi bir tamamlayıcı ve alternatif tedavi yöntemi kullanmış ve \%97.8'i yöntemin etkili olduğunu ifade etmiştir. Eğitim durumu yüksek olanlarda, ev hanımı ya da emekli olanlarda, vajinal duş yapanlarda, kronik bir hastalığı veya inkontinansı olanlarda TAT kullanımı daha yaygındır. Bir yılda üçten fazla sayıda IYE tanısı alanlarda TAT kullanımı daha azdır.

Sonuç: En sık kullanılan bitkisel yöntemler; maydanoz, kuşburnu, yeşil çay, ısırgan, ıhlamur, kekik ve papatyadır. En sık kullanılan besinsel yöntemler; yoğurt, süt ve süt ürünleri, bal, nar, sarımsak, en sık kullanılan dini yöntemler; dua etmek ve namaz, en sık kullanılan ruhsal yaklaşım ise egzersizdir.

Anahtar Kelimeler: Idrar yolu enfeksiyonu, tercih, kadın, tamamlayıcı ve alternatif tedavi yöntemleri 


\section{INTRODUCTION}

Urinary tract infections (UTIs) are the microbial infiltration of the sterile urinary tract and are one of the most frequently seen bacterial infections across the world. UTIs covers urethra (urethritis), urinary bladder (cystitis), ureter (urethritis) and kidney (pyelonephritis) infections. It is estimated that annually more than 8 million UTIs people suffer from in the United States and many of them consult a physician. About $1 \%$ of patients diagnosed with UTIs receive antibiotic treatment requiring hospitalization. ${ }^{[1]}$

UTIs are one of the most common bacterial infections affecting women. In particular, they affect $50-60 \%$ of young and sexually active women. Approximately one in three women gets antibiotic treatment before the age of 24 , the infection is repeated within 6 months and the UTI attack is experienced at least once in one-fourth of women ${ }^{[2]}$ UTIs in Turkey is one of the most common infections in outpatient services in both in inpatient facilities. According to reports from Turkey, $21-49 \%$ of hospital-acquired infections are urinary tract infections. ${ }^{[3]}$ The passage of fecal bacteria in the urinary tract is easier in women than in men because of the shorter urethra, the proximity of the urethral meatus to the anus and the anatomical structure of women. In addition, among other risk factors, the diagnosis of UTIs before the age of 15 years, the history of UTIs in the mother or previous experience with UTIs and the use of spermicides as a method of contraception play a part. ${ }^{[2]}$ The colonization of gastrointestinal pathogens during the coitus, urinary system obstruction, incomplete micturition, abnormal anatomical structure and low vaginal estrogen level are among the causes of UTIs as well. ${ }^{[4]}$

Recurrent UTIs are the occurrence of three infections in one year or more than two infections in six months. The main symptoms of UTIs are dysuria, frequent urination, cloudy urine and sometimes hematuria. ${ }^{[5]}$ In general, UTIs without complications are limited to the bladder and are healed rapidly after antibiotic treatment. For this reason, they are less serious, but it can causes long-term sequelae. Even if they are not seen as very disturbing, UTIs without complications decreases the quality of life and productivity of the patient. In a study carried out with women studying at the university, among the patients diagnosed with UTIs it was reported that for 2.4 days their activity was limited, for 1.2 days they lost time and for 0.4 days they were confined to bed due to symptoms. ${ }^{[6]}$

The total cost associated with community-based UTIs including doctor visits, antibiotic prescriptions, hospitalizations and sick leave is reported to be approximately $\$ 1.6$ billion each year in the United States. ${ }^{[7]}$ For the treatment of UTIs, multiple antibiotic treatments are used in general, and afterward, resistance to the drugs develops. Effective alternative and complementary therapies are important especially for the treatment of recurrent UTIs. Herbal products are widely used although there are not many studies on such products used to relieve urinary symptoms. The leaf extract of Arctostaphylos uva-ursi (uva-ursi or bearberry) has been approved by the German Federal Institute of Drugs and Medical Devices for the use of urinary tract inflammation and is supplied with a prescription in Germany. It is reported that these plants have diuretic, urinary antiseptic and anti-inflammatory properties. Extract components include flavonoids, iridocyte, hydroquinone glycosides (mainly arbutine), tannins and terpenoids. ${ }^{\left[{ }^{[8]}\right.}$ There is evidence that the Uva-Ursi plant is used in the United Kingdom to relieve symptoms of acute UTIs. In a study carried out with 309 women, it was reported that uvacin which contains uva-ursi was reduced the duration of the disease. However, although the numbers that indicate the use of the product are low, the recommended rates are high. ${ }^{[9]}$

In studies in Turkey it is widely used Complementary and Alternative Medicine (CAM) method. There are many studies especially on cancer, menopausal period, infertility, diabetes, metabolic diseases..$^{[10-12]}$ However, as a result of the literature review, there are insufficient number of studies on CAM methods and effects used for UTI. In fact, there is no study about the methods used CAM to treat UTI in Turkey. The aim of the present study was, to determine the causes of UTIs in women in Turkey, the infection as well as the complementary and alternative treatment methods they prefer to cope with it.

\section{MATERIAL AND METHOD}

\section{Sampling Technique, Inclusion Criteria}

The study is quantitative, descriptive and cross-sectional. The study was carried out in Gümüşhane, a province of the Eastern Black Sea region. The level of education is below the average in Turkey. The research population was composed of women who applied to a public hospital urology and gynecology polyclinic in Gümüşhane. The sample consists of 180 women who were reached between 20.02.2018-20.06.2018 and have the criteria for inclusion in the study. Women who applied to outpatient clinics, able to communicate in Turkish; were between the ages of 20-65 and diagnosed with UTI in the past year were included in the study. Patients who had a social or psychological status that would prevent them from participating in the study, women who were newly diagnosed and patients who did not wish to participate in the study after being informed of it were excluded.

\section{Data Collection}

In order to collect the data comfortably and safely, women were interviewed in a suitable outpatient clinic. The purpose of the study was explained to the participants, verbal consent was obtained from those who wanted to participate in the study and data were collected. A woman was interviewed for about 20 minutes.

Descriptive Information Form, and Complementary and Alternative Medicine Scale (CAMS) were used in the collection of the study data. The Descriptive Information Form consists of two parts. The first part questions the socio-demographic characteristics and the second part questions the risk factors for UTIs and includes questions about perineum hygiene, chronic diseases, family planning methods, sexually transmitted infections and UTIs. 
Complementary and Alternative Medicine Scale: The Complementary and Alternative Medicine Scale was improved by Can et al. The scale consists of five subgroups of 55 CAM interventions often used. The five subgroups are as follows: herbal supplement subgroup (29 items), religious practices subgroup ( 5 items), mind-body practices subgroup (5 items), biological practices subgroup (3 items) and dietary supplement subgroup (14 items). CAMS assesses the use of individual CAM methods by dichotomous responses, where 0 means "no" and 1 means "yes". Sub-dimension scores were estimated by summing up the scores of individual items and the total score of the scale is the sum of individual subdimension scores. The Kuder-Richardson 20 (KR20) coefficient for the scale was $0.84 .{ }^{[13]}$

\section{Ethical considerations}

The required permission to conduct the study was obtained from the administration unit of the Health Directorate and from the Scientific Research and Publication Board of XXX University (Number=95674917-604.01.02). Eligible women were informed about the study. Verbal consent was obtained from the women, who accepted to participate in the study. Each woman was interviewed for 15 minutes to fill in the data collection questionnaire.

\section{Data Analysis and Interpretation}

The data obtained as a result of the research were evaluated with SPSS-22 program, error checks, tables and statistical analyzes were made. Numbers and percentages are given in statistical evaluations. Before normality analysis, missing data and extreme value extractions were made. Afterwards, histogram drawings were made for compliance with normal distribution, skewness and kurtosis values were examined, and Kolmogorov-Smirnov analyzes were performed. After all the steps, logarithmic transformations were applied to the CAMS, which did not show normal distribution, but it was determined that normal distribution conditions did not occur. Therefore, in order to determine whether independent variables make a difference on CAM, Mann-Whitney $U$ and Kruskal Wallis tests was performed. $p<0.05$ was accepted as statistical significance level.

\section{RESULTS}

Some socio-demographic characteristics of the women are shown in Table 1. The mean age of the participants was $40.21 \pm 15.42$ ( $\min =18, \max =65$ ). $45.0 \%$ of the participants were primary school graduates, $61.1 \%$ were housewives/ reired, and the income of $58.3 \%$ of the women equaled to their expenses.

The mean Body Mass Index (BMI) of the women was $26.05 \pm$ $5.05(\min =15, \max =43)$ and the mean number of pregnancies was $2.91 \pm 2.71 \quad(\min =0, \max =12)$. Some characteristics of genital hygiene are shown in Table 2.

\begin{tabular}{lcc} 
Table 1. Some socio-demographic characteristics of women & \\
\hline Educational Background & $\mathbf{n}$ & $\%$ \\
\hline Primary school graduate & 81 & 45.0 \\
Secondary/high school graduate & 38 & 21.1 \\
University graduate & 61 & 33.9 \\
Total & 180 & 100.0 \\
\hline Income status & $\mathbf{n}$ & $\%$ \\
\hline Income is less than Expense & 66 & 36.7 \\
Equal Income\&Expense & 105 & 58.3 \\
Income is much more than Expense & 9 & 5.0 \\
Total & 180 & 100.0 \\
\hline Employment Status & $\mathbf{n}$ & $\%$ \\
\hline Housewife /Retired & 110 & 61.1 \\
Employed & 37 & 20.6 \\
Student & 33 & 18.3 \\
Total & 180 & 100.0 \\
\hline Abode & $\mathbf{n}$ & $\%$ \\
\hline Married & 127 & 70.6 \\
Single/Separated & 52 & 29.4 \\
Total & 179 & 100.0 \\
\hline
\end{tabular}

Forty-six percent of the women changed their pad every 3-4 hours during menstruation period, $51.1 \%$ performed vaginal douching (wash the vagina), 58.9\% of them wore cotton underwear and $32.2 \%$ of them complained of urinary incontinence. $73.4 \%$ of the participants were diagnosed with more than one UTI in one year.

As a result of the evaluation of some variables of the participants diagnosed with a UTI in one year it was found that housewives, those with low education level, who wash their hands only after leaving the toilet, those who washed from the front to the back, the ones who perform vaginal douching, those who do not care to wear cotton underwear were more likely to experience a UTI in a year $(p<0.05)$. There were no statistically significant differences in the prevalence of UTI diagnoses within a year due to income status, smoking, the number of pad changes, the frequency of changing underwear, being sexually active and urinary incontinence $(p>0.05)$.

The number of women diagnosed with UTI in a year; was high in housewifes $\left(X^{2}=17.884, p=0.007\right)$, those with low education levels $\left(X^{2}=19.124, p=0.004\right)$, those who performed vaginal douching $\left(X^{2}=9.499, p=0.023\right)$, those with chronic diseases $\left(X^{2}=13.012, p=0.0009\right)$ and those with urinary incontinence complaints $\left(X^{2}=12.939, \mathrm{p}=0.005\right)$.

Almost all of the women who participated in the study stated that they used a CAM method for UTIs (92.8\%) and $97.8 \%$ of them expressed that the method was effective. CAM methods used by women with UTI diagnosis are shown in Table 3.

The use of CAM was common in women diagnosed with UTI (73.3\% of them used herbal, $75.6 \%$ nutritional, $76.7 \%$ religious and $17.8 \%$ psychological approaches). The most commonly used herbal methods were parsley, rosehip, green tea, nettle, linden, thyme and chamomile; the dietary methods were yogurt, milk and dairy products, honey, pomegranate, garlic; religious methods were prayers and the psychical approach was exercise. 
Table 2. Some characteristics of women concerning genital hygiene The frequency of changing pad

1-2 hours

3-4 hours

5-6 hours

6 hours or more

Total

\section{Cleanliness}

With water

With toilet paper

With water and toilet paper

With water and soap

Total

Frequency of changing underwear

One time per week

Two-three times per week

Daily

2 times a day

Total

Sexual activity

Yes

No

Total

How many times a year diagnosed with UTI

Once

Two-three times

Four-five times

Six and more times

Total

Birth control (BC) method

Yes

No

Total

The vaginal douching

Yes

No

Total

Handwashing

Before toilet

After toilet

Before and after toilet

Do not care

Total

How the cleanliness provided

Front to back

Back to front

Do not care

Total

Underwear feature

I wear cotton underwear

I wear synthetic underwear

Do not care

Total

STI experience

Yes

No

Total

Urinary incontinence

Often

Occasionally

Rarely

Never

Total

Preferred BC methods

Contraceptives

Intrauterine device

Condom

Withdrawal method

Tubal ligation

Total

UTI: Urinary tract infections, BC: Birth control, STI: Sexually Transmitted Infections $\%$

\begin{tabular}{cc}
$\mathbf{n}$ & $\%$ \\
\hline 26 & 20.6 \\
58 & 46.0 \\
26 & 20.6 \\
16 & 12.8 \\
126 & 100.0 \\
$\mathbf{n}$ & $\%$ \\
49 & 27.2 \\
12 & 6.6 \\
118 & 65.6 \\
1 & 0.6 \\
180 & 100.0 \\
$\mathbf{n}$ & $\%$ \\
11 & 6.1 \\
97 & 53.9 \\
60 & 33.3 \\
12 & 6.7 \\
180 & 100.0 \\
\hline
\end{tabular}
$\%$

54.4

45.6 100.0

180

n

$\begin{array}{ll}48 & 26.6 \\ 64 & 35.6\end{array}$

$34 \quad 18.9$

$34 \quad 18.9$

$180 \quad 100.0$

$\begin{array}{cc}\text { n } & \% \\ 70 & 38.8\end{array}$

$110 \quad 61.2$

$180 \quad 100.0$

$\begin{array}{cc}\text { n } & \% \\ 92 & 51.1\end{array}$

$88 \quad 48.9$

$180 \quad 100.0$

$\begin{array}{cc}\mathbf{n} & \% \\ 3 & 1.7\end{array}$

$109 \quad 60.6$

$66 \quad 36.6$

21.1

$180 \quad 100.0$

$\begin{array}{cc}\text { n } & \% \\ 102 & 56.7\end{array}$

$64 \quad 35.6$

$14 \quad 7.8$

$180 \quad 100.0$

$106 \quad 58.9$

$\begin{array}{ll}106 & 2.8\end{array}$

$69 \quad 38.3$

$180 \quad 100.0$

$\begin{array}{cc}\text { n } & \% \\ 18 & 10.0\end{array}$

$162 \quad 90.0$

$180 \quad 100.0$

$\begin{array}{cc}\text { n } & \% \\ 30 & 16.7\end{array}$

$27 \quad 15.0$

$1 \quad 0.6$

$122 \quad 67.7$

$180 \quad 100.0$

$\begin{array}{cc}\mathbf{n} & \% \\ 8 & 11.5\end{array}$

$20 \quad 28.5$

$11 \quad 15.8$

$28 \quad 40$

34.2

$\begin{array}{ll}70 & 100.0\end{array}$
Table 3. Use of CAM Therapies* $(n=356)$

Herbal supplements

VStinging nettle

Rosehip

Linden tea-

Grape seed

Daisy

Green tea

Sage tea

Nigella sativa

Blueberries

Mallow

Ginger

Sweet almond

Curcuma

Flax seed

Vitamin

Centaury

Thyme

Yarrow

Juniper

Omega 3

Other

Onion juice

Apple cider vinegar

Cherry stalk

Parsley

Mind-body practices

Exercise

Meditation

Yoga

Acupuncture

22.8
$95-528$

23.9

2.2

18.9

28.3

9.4

10.6

1.7

2.2

6.1

1.1

3.3

0.6

6.7

1.7

15.6

1.1

0.6

1.7

Music

Dietary supplements

Yoghurt

Milk and milk products

Honey

Carob syrup

Anzer honey

Mullberry syrup

Chestnut honey

Pomegranate

Grapefruit

Garlic

Carrot

Other fruits and vegetables

Red meat

Fish

Chicken

Bread/pastry

Sweet-tat

Other (kefir)

Religious practices

Namaz**

Pray

Carry written amulet

Visit place where holy man is bruied

Biological practices

* Some patients used more than one CAM therapy so the percentages of CAM use are given according

to the related item.
** Namaz= Prayer performed by Muslims five times a day. 
The methods used by the participants for coping with UTIs were drinking plenty of water, particularly making hot application to feet and taking a warm shower. The comparison of sub-dimension and total score averages of CAM scale according to the characteristics of the participants is shown in Table 4.

The use of CAM methods was more common in those with higher education, housewifes or retired, women, those who performed vaginal douching had chronic diseases or incontinence. The use of CAM methods was less in patients who suffered from more than three UTIs in a year and there was a significant difference between them.

\section{DISCUSSION}

UTIs are very common in the community, can be easily treated and can cause morbidity, and sometimes, although very rarely, cause mortality. UTIs are bacterial infections that are most common among females and reduce the quality of life. ${ }^{[14]}$ Although they require proper antibiotic treatment, 30-50\% of women who have UTIs have a recurrent infection in 6-12 months. The chronic recurrent UTIs (more than two in one year) are present in $2-5 \%$ of women. ${ }^{[15]}$ It was reported in a study that women had a higher risk of contracting a second UTI after the first one, and $20 \%$ of patients had a recurrence within 6 months. ${ }^{[16]}$ In this study, it was observed that the rate of women diagnosed with more than one UTI in a year was $73.4 \%$. The rate of women diagnosed with four or more was $37.8 \%$. The woman diagnosed with UTIs once had a risk for subsequent infections.

Table 4. Comparison of sub-dimension and total score averages of CAM scale according to characteristics of the participants

\begin{tabular}{|c|c|c|c|c|c|}
\hline & $\begin{array}{l}\text { Herbal Approaches } \\
\text { Median (\%95 Cl) }\end{array}$ & $\begin{array}{l}\text { Nutritional Approaches } \\
\text { Median (\%95 Cl) }\end{array}$ & $\begin{array}{l}\text { Religious Approaches } \\
\text { Median (\%95 Cl) }\end{array}$ & $\begin{array}{l}\text { Spiritual Approaches } \\
\text { Median (\%95 Cl) }\end{array}$ & $\begin{array}{c}\text { Total } \\
\text { Median }(\% 95 \mathrm{Cl})\end{array}$ \\
\hline \multicolumn{6}{|c|}{ Educational Background } \\
\hline Primary & $2.00(1.97-2.86)$ & $2.00(1.77-2.76)$ & $2.00(1.29-1.74)$ & $0.00(0.10-0.28)$ & $6.00(5.44-7.37)$ \\
\hline Secondary/high & $2.00(1.78-3.00)$ & $2.00(2.03-2.65)$ & $2.00(1.46-2.00)$ & $0.00(0.11-0.40)$ & $7.00(5.78-7.69)$ \\
\hline University & $1.00(1.09-1.95)$ & $2.00(1.62-2.73)$ & $2.00(1.07-1.54)$ & $0.00(0.02-0.17)$ & $5.00(4.13-6.09)$ \\
\hline \multirow{2}{*}{ Test value } & $K W=9.193$ & $\mathrm{KW}=1.683$ & $\mathrm{KW}=4.050$ & $\mathrm{KW}=4.717$ & $\mathrm{KW}=7.314$ \\
\hline & $p=0.010$ & $p=0.431$ & $p=0.132$ & $p=0.095$ & $p=0.026$ \\
\hline \multicolumn{6}{|l|}{ Employment Status } \\
\hline Housewife & $2.00(2.00-2.75)$ & $2.00(1.89-2.63)$ & $2.00(1.39-1.75)$ & $0.00(0.10-0.25)$ & $6.00(5.64-7.15)$ \\
\hline Employed & $1.00(1.25-2.47)$ & $2.00(1.55-2.55)$ & $2.00(1.09-1.77)$ & $0.00(0.05-0.32)$ & $5.00(4.36-6.71)$ \\
\hline Student & $1.00(0.92-2.04)$ & $2.00(1.55-3.35)$ & $2.00(0.97-1.62)$ & $0.00(0.02-0.28)$ & $5.00(3.92-6.85)$ \\
\hline \multirow{2}{*}{ Test value } & $\mathrm{KW}=6.261$ & $\mathrm{KW}=0.047$ & $\mathrm{KW}=2.034$ & $\mathrm{KW}=0.200$ & $\mathrm{KW}=2.877$ \\
\hline & $p=0.044$ & $p=0.977$ & $p=0.362$ & $p=0.905$ & $p=0.237$ \\
\hline \multicolumn{6}{|c|}{ The vaginal douching } \\
\hline Yes & $2.00(1.85-2.66)$ & $2.00(1.92-2.70)$ & $2.00(1.32-1.71)$ & $0.00(0.14-0.31)$ & $7.00(5.54-7.10)$ \\
\hline No & $2.00(1.55-2.35)$ & $2.00(1.74-2.64)$ & $2.00(1.26-1.67)$ & $0.00(0.05-0.19)$ & $5.00(4.86-6.61)$ \\
\hline \multirow{2}{*}{ Test value } & $U=3651.000$ & $U=3751.000$ & $U=3958.500$ & $U=3630.000$ & $\mathrm{U}=3544.000$ \\
\hline & $p=0.247$ & $p=0.386$ & $p=0.772$ & $p=0.071$ & $p=0.148$ \\
\hline \multicolumn{6}{|c|}{ Chronic disease condition } \\
\hline Yes & $2.00(1.69-2.64)$ & $2.00(1.88-2.88)$ & $2.00(1.39-1.83)$ & $0.00(0.06-0.24)$ & $7.00(5.39-7.25)$ \\
\hline No & $2.00(1.72-2.43)$ & $2.00(1.81-2.54)$ & $2.00(1.24-1.60)$ & $0.00(0.11-0.26)$ & $5.00(5.12-6.62)$ \\
\hline \multirow{2}{*}{ Test value } & $\mathrm{U}=3622.500$ & $U=3517.000$ & $U=3367.000$ & $U=3597.500$ & $\mathrm{U}=3379.000$ \\
\hline & $p=0.727$ & $p=0.503$ & $p=0.212$ & $p=0.529$ & $p=0.284$ \\
\hline \multicolumn{6}{|c|}{ Diagnosis of UTI in one year } \\
\hline Once & $2.00(1.43-2.69)$ & $2.00(1.76-2.86)$ & $2.00(1.50-2.04)$ & $0.00(0.05-0.27)$ & $5.50(5.10-7.51)$ \\
\hline Twice-Thrice & $2.00(1.89-2.82)$ & $3.00(2.26-3.38)$ & $2.00(1.35-1.79)$ & $0.00(0.11-0.32)$ & $7.00(5.92-8.03)$ \\
\hline 4-5 times & $1.00(0.96-2.03)$ & $2.00(1.14-2.02)$ & $1.00(0.74-1.48)$ & $0.00(0.02-0.27)$ & $4.00(3.37-5.33)$ \\
\hline 6 and more & $2.00(1.65-2.99)$ & $2.00(1.05-2.47)$ & $2.00(1.01-1.62)$ & $0.00(0.02-2.49)$ & $6.00(4.30-6.81)$ \\
\hline \multirow{2}{*}{ Test value } & $\mathrm{KW}=5.666$ & $\mathrm{KW}=12.380$ & $K W=11.291$ & $\mathrm{KW}=1.208$ & $\mathrm{KW}=10.420$ \\
\hline & $p=0.129$ & $p=0.006$ & $p=0.010$ & $p=0.751$ & $p=0.015$ \\
\hline \multicolumn{6}{|l|}{ Incontinence status } \\
\hline Yes & $2.00(1.92-2.90)$ & $2.00(1.59-2.61)$ & $2.00(1.26-1.76)$ & $0.00(0.11-0.33)$ & $6.50(5.34-7.17)$ \\
\hline No & $2.00(1.62-2.31)$ & $2.00(1.96-2.69)$ & $2.00(1.31-1.65)$ & $0.00(0.09-0.22)$ & $5.00(5.18-6.67)$ \\
\hline \multirow{2}{*}{ Test value } & $U=2986.000$ & $\mathrm{U}=3336.000$ & $\mathrm{U}=3514.500$ & $U=3296.000$ & $U=3209.00$ \\
\hline & $p=0.085$ & $p=0.528$ & $p=0.935$ & $p=0.263$ & $p=0.312$ \\
\hline
\end{tabular}


Sexual contact, no micturition, the use of spermicidal gel, the use of diaphragm, pregnancy, low socioeconomic status, diabetes, sexually transmitted infections, vaginal douching, daily use of pads, hygienic behavior and history of recurrent infection are risk factors for UTIs in women. ${ }^{[16.17]}$ In this study, approximately half of the women diagnosed with UTIs were primary school graduates, $61.1 \%$ were housewives and $70.6 \%$ were married. When the hygiene behaviors of the participants were examined it was found that only $36.7 \%$ of the participants washed their hands before and after going to the toilet, $56.7 \%$ cleaning from front to back, $10 \%$ had Sexually Transmitted Diseases (STDs), and 51.1\% performed vaginal douching. UTI diagnosis was high in housewives, in those with low education level, in those who washed their hands only after leaving the toilet, in those who washed from back to front in those who performed vaginal douching, in those who do not pay attention to the choice of underwear, and in those who have chronic disease and urinary incontinence.

According to the latest studies in UTI management, it has been reported that the use of Chinese herbal medicines alone or with medicines are beneficial. It was also reported that it prevented infections, which were recurrent at least six months later. ${ }^{[18]}$ Almost all of the women participated in the study stated that they used a CAM method for UTI (92.8\%) and $97.8 \%$ of them expressed that the method was effective. It was determined that women did not only use biological methods. The most commonly used herbal methods were parsley, rosehip, green tea, nettle, linden, thyme and chamomile; dietary methods were yogurt, milk and dairy products, honey, pomegranate, garlic; religious methods were prayers and the psychological approach was exercise. It was determined that they did not prefer only biological methods. In the last review studies, 4 alternative approaches other than drugs were recommended. These were cornelian cherry, prebiotic, Chinese herbal medicine and D-mannose. It has been emphasized that prebiotics are not very effective when mixed with placebo or when used alone. It was also reported that the efficacy was high with medical treatment. ${ }^{[19]}$ Some of the fruit juices used have been reported to be effective. Especially the use of bilberry for a long time was reported to be effective in reducing UTI complaints. The use of cornelian cherry juice for 12 months was reported to reduce the frequency of UTI and to be effective for the regression of symptoms. ${ }^{[20]}$

It is recommended to use CAM methods especially to prevent recurrent infections, to increase the effectiveness of treatment, to reduce the side effects and the treatment costs. There are many uses of CAM in some countries and the studies about endemic methods continue. For example, traditional methods are commonly used in China to treat various pathologies, including chronic and refractory infectious diseases. ${ }^{[21]} 33$ women with more than 3 UTIs per year were included in a study. Annual UTI incidence of the women was determined as $6.6+2.5 .4$ weeks-treatment consisting of 10 plants (Rhizoma Anemarrhenae, Cortex Phellodendri
Chinensis, Angelica sinensis, Rehmannia glutinosa, Libosch, Wolfiporiacocos, Salvia miltiorrhiza, Rhubarb, Polygonum aviculare L., Dianthus superbus, and Talcum) was applied to women who were resistant to at least 8 antibiotics. After 2 weeks, 25 patients (73.52\%) experienced significant symptomatic relief; in 4 weeks, 30 patients $(88.23 \%)$ recovered; and 3 patients (7.5\%) did not come around. Recurrence was observed in only 4 (11.76\%) of the patients recovered after 6 months of follow-up and this rate was indicated to be a much lower than the antibiotic treatment. No adverse effects were reported among these cases. ${ }^{[2]}$ In the study, it was found that almost all of the women used CAM. In particular, various herbal and dietary sources were preferred. The vast majority of women drunk parsley and rosehip juice, and consumed milk, milk products and yoghurt. Staying hydrated and warm applications were also used to cope. In a study, many methods were recommended for UTIs as well as the elimination of many ailments. Staying hydrated, sweet juicy fruit (grape, pear, plum, mango, melon, apple), pumpkin, yellow squash, cucumber, organic food were recommended to be eaten. ${ }^{[23]}$

In this study, the use of the CAM method was more common in; housewives, those who have a high educational level and perform vaginal douching, those with a chronic disease and incontinence. In addition, the use of the CAM method was less in those who were diagnosed with more than three UTIs in a year.

\section{CONCLUSIONS}

As a result of the research; genital hygiene behaviors were determined to affect the frequency of UTI diagnosis. Almost all women with UTIs use a CAM method (\%92.8). It was found that the women with UTIs especially preferred; parsley, rosehip, green tea, nettle, linden, thyme and chamomile as herbal methods; yogurt, milk and dairy products, honey, pomegranate, garlic as dietary methods; prayers as religious methods and exercise as psychological approach. Almost all women using the method stated that the method was effective (97.8\%).

It is necessary to prevent UTIs to reduce health cost and improve women's quality of life. It is very important to raise awareness for improper practices. Women's CAM methods and their effects on health must be researched. It is recommended to determine the methods varying by countries and regions and to carry out comprehensive researches.

\section{ETHICAL DECLARATIONS}

Ethics Comittee Approval: The study was carried out with the permission of the Scientific Research and Publication Board of Gümüşhane University (Number=95674917-604.01.02).

Informed Consent: The study was conducted on a voluntary basis. Verbal consent was obtained from the participants.

Status of Peer-review: Externally peer-reviewed. 
Conflict of Interest Statement: The authors have no conflicts of interest to declare.

Financial Disclosure: The authors declared that this study has received no financial support.

Author Contributions: All of the authors declare that they have all participated in the design, execution, and analysis of the paper, and that they have approved the final version.

\section{REFERENCES}

1. Dielubanza EJ, Schaeffer AJ. Urinary tract infections in women. Med Clin North Am 2011;95:27-41.

2. Asma B, Vicky L, Stephanie D, Yves D, Amy H, Slyvie D. Standardised high dose versus low dose cranberry Proanthocyanidin extracts for the prevention of recurrent urinary tract infection in healthy women [PACCANN]: a double blind randomised controlled trial protocol. BMC Urol 2018;18(29):1-7.

3. Yürüyen $C$, Gürol Y, Kaleağasioğlu SF, Kaspar EÇ, Yılmaz G. Isolation rates and antibiotic susceptibilities of different enterobacteriaceae species as urinary tract infection agents in Turkey: a systematic review. Turk J Med Sci 2017;47:979-86.

4. Barber AE, Norton P,SpivakAM, Mulvey MA.UrinaryTractInfections:Current and Emerging Management Strategies. Clin Infect Dis 2013;57(5):719-24.

5. Dason S, Dason JT, Kapoor A. Guidelines for the diagnosis and management of recurrent urinary tract infection in women. Can Urol Assoc J 2011;5(5):316-22.

6. Foxman B, Frerichs RR. Epidemiology of urinary tract infection:I.Diaphragm use and sexual intercourse. Am J Public Health 1985;75(11):1308-13.

7. Ennis SS, Guo H, Raman L, Tambyah PA, Chen SL, Tiong Y. Premenopausal women with recurrent urinary tract infections have lower quality of life. Int J Urol 2018;22:1-7.

8. European Medicines Agency (EMA). Assessment report on Arctostaphylos uva-ursi. Spreng. Folium, 2012. Available at: https://www.ema.europa. eu/en/documents/herbal-report/superseded-assessment-reportarctostaphylos-uva-ursi-I-spreng-folium-revision-1_en.pdf

9. Little $\mathrm{P}$, Moore $\mathrm{M}$, Turner SM, Rumsby K. Effectiveness of five different approaches in management of urinary tract infection:randomised controlled trial. BMJ 2010;340:199.

10. Özcan H, Çolak P, Oturgan B, Gulsever E. Complementary and alternative treatment methods for menopausal hot flashes used in Turkey, AJOL 2019;19(4):3001-8.

11. Cevik C, Tari Selcuk K. Prevalence and correlates of the use of complementary and alternative medicine in adults living in a rural area, Holist Nurs Pract 2019;33:36-44.

12. Süzer Özkan F, Karaca A, Sarak K. Complementary and Alternative Medicine Used by Infertile Women in Turkey. Afr J Reprod Health 2018;22:40-8.

13. Can G, Erol O, Aydiner A, Topuz E. Quality of life and complementary and alternative medicine use among cancer patients in Turkey. EJON 2009;13(4):287-94.

14. Nguyen HT. Bacterial infections of the genitourinary tract.In:Tanagho EA, McAninch JW, editors. Smith's General Urology 17th ed. New-York: McGraw-Hill Pres 2008;(13):193-213

15. Foxman B. The epidemiology of urinary tract infection. Nat Rev Urol 2010;7:653-60.

16. Sobel JD, Kaye D. Urinary tract infections. In: Mandell GL, Bennet JE, Dolin $\mathrm{R}$ (eds). Principles and Practice of Infectious Diseases. 6th ed. Philadelphia: Churchill Livingstone, 2005:875-905.

17. Dalbudak S, Bilgili N. Genital hygiene behaviors and their effect on vaginal infection of the women who apply to GATA women's illnesses and birth clinic. Gulhane Med J 2013;55:281-7

18. Flower A, Wang LQ, Lewith G, Liu PJ, Li Q. Chinese herbal medicine for treating recurrent urinary tract infections in women. Cochrane Database Syst Rev 2015;6:CD010446.
19. Schwenger EM, Tejani AM, Loewen PS. Probiotics for preventing urinary tract infections in adults and children. Cochrane Database Syst Rev 2015;12:CD008772.

20. Jepson RG, Williams G, Craig JC. Cranberries for preventing urinary tract infections. Cochrane Database Syst Rev 2012;17(10):CD001321.

21. Jiang WY. Therapeutic wisdom in traditional Chinese medicine:a perspective from modern science. Trends Pharmacol Sci 2005;26:558-63.

22. Zhang N, Huang L, Liu S, et al. Traditional Chinese Medicine: An Alternative Treatment Option for Refractory Recurrent Urinary Tract Infections. Clin Infect Dis 2013;56(9):1355.

23. Amanak K, Karaöz B, Sevil Ü. Alternative / Complementary Medicine and Women's Health. TAF Prev Med Bull 2013; 12(4):441-8. 